\title{
Application of Option Pricing Model in Business Evaluation for High-tech Enterprise
}

\author{
Lian Xue $\mathrm{e}^{1, \mathrm{a}^{*}}$ \\ ${ }^{1}$ School of Computer and Computing Science, Zhejiang University City College Hangzhou, 310015, \\ P.R. China \\ $a^{*}$ xuel@zucc.edu.cn
}

Keywords: Options; Business Evaluation for Hi-Tech Enterprise; Black-Scholes Option Pricing Model; Volatility

\begin{abstract}
This paper illuminates intrinsic value and behavior of premium option based on expounding exactly the definition of option. To modify the model fit for long-term option and short-term option with variables as Expiration date and dividend-paying policy by numbers of empirical studies, this paper explains calculating way of dividend yield and volatility, then uses that into cases analysis and introduces valuation steps, which make option pricing method more applied, simplified and procedure.
\end{abstract}

\section{Introduction}

The world width surging wave of the venture investment makes the High-tech enterprise prosperous and new vigor to the social economy of the 21 st century. Jack Welch, centering on improving the value of the company, create unprecedented growing miracle of the GE. Due to the development of newer a mainly come from the potential value of intangible assets and intellectual property rights, thus strengthening technology innovation, development, "high-tech industrialization", has become the power of social development. In order to reflect the development potential of high-tech enterprises and value more fair, practical and accurately, from the contribution of 1997 annual Nobel economic prize winner Myron Scholes and Robea C.Merton Black -- Scholes formula, option pricing method become intangible assets assessment- a powerful tool for value of future opportunities, reveals the potential value of the enterprise effectively. But we find that B - S model for high-tech enterprises existing distortion valuation in the demonstration, only some key factors making main effect. This passage, by analyzing the basic theory of options in the enterprise asset evaluation with options, finds the key variables, and the improved valuations.

\section{The Modification of Black-Scholes Option Pricing Model Applied in Business Evaluation for High-Tech Enterprise}

Note: "+" Indicates the option price is an increasing function of variables, "One" means the option price is a decreasing function of variables. B-S Option Pricing Theory [1] [2] [3] and the basic form is as follows:

The application of the B-S model is simple than the application of binomial option pricing method. The existing building basic assumptions [4]:

(1) Underlying asset price follows geometric evolution Br0wn movement:

$\frac{d S}{S}=\mu d t+\sigma d W t$

$\mu$ Is the Expected rate of return, $\sigma$ is Volatility, $d W t$ is standard Brown Activity, $E\left(d W_{t}\right)=0$, $\operatorname{Var}\left(d W_{t}\right)=d_{t}$.

(2) Don't pay the transaction cost and tax. It means the market is no friction. 
(3) The underlying asset doesn't pay dividends.

(4) The risk-free rate $r$ is constant.

Assume the market value of the underlying asset $S$, the option exercise price $\mathrm{X}$, the call option price $C_{t}$, the put option price $P_{t}$, volatility $\sigma$, effective time $T-t$, the risk-free rate $\mathrm{r}$, mainly use (risk hedge principle) hedge [5]:

$\coprod=\mathrm{V}-\Delta \mathrm{S}$

That is given the option $\mathrm{V}$, share trading in the opposite direction of the underlying asset $\mathrm{S}$, to form risk-free portfolio $\amalg$.

The Parity formula of the call options - pit options:

$C_{t}+X e^{-r(T-t)}=P_{t}+S$

Calculated step by step to derive Black-Scboles option pricing formula:

$C_{t}=V(S, t)=S N\left(d_{1}\right)-X e^{-r(T-t)} N\left(d_{2}\right)$

The first in the right is expected value of the assets in the formula; the second is the expected cost for the assets, among:

$$
\begin{aligned}
d_{1} & =\frac{\ln (S / X)+\left(r+\sigma^{2} / 2\right)(T-t)}{\sigma \sqrt{T-t}} \\
d_{2} & =\frac{\ln (S / X)+\left(r-\sigma^{2} / 2\right)(T-t)}{\sigma \sqrt{T-t}} \\
& =d_{1}-\sigma \sqrt{T-t} \\
P_{t} & =V(S, t)=X e^{-r(T-t)} N\left(-d_{2}\right)-S N\left(-d_{1}\right)
\end{aligned}
$$

B - S model can not only be used for the option pricing, in the practical operation can also use $\Delta$ - to train risk assets management. One option is selling party sold to avoid risk, must take this risk, selling party. When the strategies of risk control, buy a train of proper share with its assets, and train a hedge.

The following is the modification of B-S option pricing model applied in business evaluation for high-tech:

Enterprise B-S option pricing model may be characteristic of any assets with the option to quantify under some conditions, especially in the risk of investment in the new project with technology patent or the value of high-tech enterprise by option evaluation method is appropriate [6].

Short-term options [7], refers to the option expires within a year. For such options, after adjustment for the underlying asset price $S^{\prime}$, the underlying asset value $S$, validity of the underlying assets estimated present value of expected dividends

$$
P V(D)=\sum\left[D_{t} /(1+r)^{t}\right]
$$

(Taking into account the number of times a year to pay dividends), Then $\mathrm{S}^{\prime}=\mathrm{S}-\mathrm{PV}(\mathrm{D})$; then will $\mathrm{B}-\mathrm{S}$ model for $S$ substitution of $S^{\prime}$, improved dividend payments of short-term option pricing model. Longterm option [8][9][10] in more than one year option period. Treatment using the present value of dividends will be more difficult and error. Here the introduction of variable adjustment model of dividend yield.

B-S model on the promotion of the original assumptions:

(1) The price of the underlying asset for random differential equations

$\frac{d S}{S}=\mu(t) d t+\sigma(t) d W t$.

(2) The underlying asset continuous to pay dividends (bonus), Dividend yield y (t) = the bonus/ present value of assets. Dividend positive cash flows from the project beginning of the year, Payment of dividends by companies accounted for the proportion of after-tax profit extraction.

In a similar way, to derive the improved dividend payments exist long-term B-S option pricing model:

$$
C_{t}=S e^{-y(T-t)} N\left(d_{1}\right)-X e^{-r(T-t)} N\left(d_{2}\right)
$$




$$
\begin{aligned}
& P_{t}=X e^{-r(T-t)} N\left(-d_{2}\right)-S e^{-y(T-t)} N\left(-d_{1}\right) \\
& d_{1}=\frac{\ln (S / X)+\left(r-y+\sigma^{2} / 2\right)(T-t)}{\sigma \sqrt{T-t}} \\
& d_{2}=d_{1}-\sigma \sqrt{T-t}
\end{aligned}
$$

The hardest of variables in $\mathrm{B}-\mathrm{S}$ model is volatility $\sigma$, the variance of the underlying assets value. According to the theory of valuation here before, and less error calculation for improvement of the underlying assets and capital budget (cash flow forecast data in the standard of measuring execution rate) $\sigma$ estimation:

$$
\sigma=\sqrt{\frac{1}{n-1} \sum_{i=1}^{n}\left(R_{i}-R\right)^{2}}
$$

(Investment profit $\mathrm{R}=$ net profit/The total investment).

\section{Empirical and Estimated Form}

The profits and losses of having the patent products $=V-I(V>I)$. The profits and losses of having the patent products $=0(V \leq I)$.

In order to make this project is feasible and sustainable development, the enterprise financial personnel in logical, according with the objective reality basis, through the corresponding industry, the market and financial basis, consider price elasticity of demand, enterprise and industry development, the influence of factors such as the evaluation setting this option prediction of investment project cash flow(Shown in Table 1).

Calculated based on data in Table 1:

(1) The current market value of the underlying asset $S=$ Present value of expected cash flows (Present value of expected cash flows) $=6$ 678.76(million);

(2) Exercise price $X=$ Investment cost of developing the present value of the product $=5474.33$ Million;

(3) Period T-t $=19$ years;

(4) On risk-free interest rate $\mathrm{r}=20$ year bond rate $=4.52 \%$;

(5) The underlying asset price volatility $\sigma=0.28$;

(6) Dividend Yield $=1.93 \%$ ( annual average, the proportion of companies paying dividends of $6 \%$ );

(7) The valuation date value of patent $V_{1}=4836.89$ million (before modification);

(8) The valuation date value of patent rights $V_{2}=2972.67$ million (improved), the net Investment value of the project is 41.7709 million Yuan.

\section{Conclusions}

Undeniably associated with various investment activities in the incidence of dividend policy. Therefore, the nature of bonus options for the evaluation of the impact of assets cannot be ignored. Through the improvement for the long-term and short-term option B - S option pricing model, volatility and dividend yield of calculation method and procedure of the measuring process theory has high. Make practical value. And through an empirical and improvement can effectively solve the problem before the option pricing, make more overvalued, reasonable price, accurate investment more rational. 
Table 1 Cash Flow Estimation and Evaluation Form(Unit: million)

\begin{tabular}{|c|c|c|c|c|c|c|c|c|c|c|c|}
\hline & Presentvalue & $\begin{array}{l}\text { The } \\
\text { First } \\
\text { Year }\end{array}$ & $\begin{array}{l}\text { The } \\
\text { Second } \\
\text { Year }\end{array}$ & $\begin{array}{l}\text { The } \\
\text { Third } \\
\text { Year }\end{array}$ & $\begin{array}{l}\text { The } \\
\text { Fourth } \\
\text { Year }\end{array}$ & $\begin{array}{l}\text { The } \\
\text { Fifth } \\
\text { Year }\end{array}$ & $\begin{array}{l}\text { The } \\
\text { Sixth } \\
\text { Year }\end{array}$ & $\begin{array}{l}\text { The } \\
\text { Seventh } \\
\text { Year }\end{array}$ & $\begin{array}{l}\text { The } \\
\text { Eighth } \\
\text { Year }\end{array}$ & $\begin{array}{l}\text { The } \\
\text { Ninth } \\
\text { Year }\end{array}$ & $\begin{array}{l}\text { The } \\
\text { Tenth } \\
\text { Year }\end{array}$ \\
\hline $\begin{array}{c}\text { The Total } \\
\text { Investment }\end{array}$ & $33^{-5474 .}$ & $\begin{array}{l}- \\
2136.60\end{array}$ & $\begin{array}{c}-2 \\
000.00\end{array}$ & $\begin{array}{c}-2 \\
000.00\end{array}$ & $\begin{array}{c}- \\
863.40\end{array}$ & I & l & l & I & l & l \\
\hline $\begin{array}{l}\quad \text { Depreciation } \\
\text { And } \\
\text { Amortization }\end{array}$ & l & $00^{475 .}$ & $.00^{475}$ & $\begin{array}{r}47 \\
5.00\end{array}$ & $\begin{array}{r}47 \\
5.00^{4}\end{array}$ & $00^{475 .}$ & $\begin{array}{c}47 \\
5.00\end{array}$ & $00^{475 .}$ & $\begin{array}{r}47 \\
5.00\end{array}$ & $\begin{array}{r}47 \\
5.00\end{array}$ & $\begin{array}{r}47 \\
5.00\end{array}$ \\
\hline $\begin{array}{l}\text { Profit After } \\
\text { Tax }\end{array}$ & / & 683. 19 & $44^{73 .}$ & $\begin{array}{r}98 \\
3.24\end{array}$ & $\begin{array}{c}2 \\
071.33\end{array}$ & $\begin{array}{c}2 \\
392.02\end{array}$ & $\begin{array}{c}3 \\
131.33\end{array}$ & $\begin{array}{c}3 \\
700.12\end{array}$ & $\begin{array}{c}3 \\
520.63\end{array}$ & $\begin{array}{c}3 \\
401.73\end{array}$ & $\begin{array}{c}3 \\
300.24\end{array}$ \\
\hline Cash Flow & l & $\begin{array}{c}-2 \\
344.79\end{array}$ & $\begin{array}{c}-1 \\
451.56\end{array}$ & 541.76 & $\begin{array}{c}1 \\
682.93\end{array}$ & $\begin{array}{c}2 \\
867.02\end{array}$ & $\begin{array}{c}3 \\
606.33\end{array}$ & $\begin{array}{c}41 \\
175.12\end{array}$ & $\begin{array}{c}3 \\
995.63\end{array}$ & $\begin{array}{c}3 \\
401.73\end{array}$ & $\begin{array}{c}3 \\
300.24\end{array}$ \\
\hline $\begin{array}{l}\text { Net Present } \\
\text { Value }(12 \%) \\
\text { Internal Rate }\end{array}$ & 6678.76 & $\begin{array}{c}-2 \\
093.56\end{array}$ & $\begin{array}{c}-1 \\
157.17\end{array}$ & $\begin{array}{c}- \\
385.62\end{array}$ & $\begin{array}{c}1 \\
069.53\end{array}$ & $6.82^{162}$ & $\begin{array}{c}1 \\
827.08\end{array}$ & $\begin{array}{c}1 \\
888.61\end{array}$ & $\begin{array}{c}1 \\
613.77\end{array}$ & $\begin{array}{c}1 \\
226.70\end{array}$ & $\begin{array}{c}1 \\
062.59\end{array}$ \\
\hline $\begin{array}{ll}\text { of } & \text { Return(10 } \\
\text { year) } & \end{array}$ & $37.49 \%$ & I & I & I & I & I & I & I & I & I & I \\
\hline $\begin{array}{c}\text { Payback } \\
\text { Period(Year) }\end{array}$ & 5.58 & l & l & l & / & l & / & / & / & / & I \\
\hline $\begin{array}{l}\text { The } \\
\text { Investment Rate }\end{array}$ & $39.99 \%$ & $12.5 \%$ & $1.3 \%$ & $\%$ & $8 \%$ & $\%$ & $2 \%$ & $\%$ & $3 \%$ & $1 \%$ & $3 \%$ \\
\hline $\begin{array}{l}\text { Dividend } \\
\text { Yield }\end{array}$ & $1.93 \%$ & 0 & 0 & 0 & $\%^{1.9}$ & $1 \%$ & $\%^{2.8}$ & $\%^{3.3}$ & $\%^{3.2}$ & $1 \%^{3 .}$ & $\%^{3.0}$ \\
\hline
\end{tabular}

\section{References}

[1] Y.Luo, The main form of incentive stock options and valuation, Beijing: Mechanical Industry Press, 2006.

[2] J.H.Forward, Options, futures and derivative securities, Beijing: Mechanical Industry Press, 2008.

[3] C.Luo, J.W.Wang, Based on the Binomial Option Pricing Model Bayesia, Beijing: QingHua University Press, 2009.

[4] S.H.Shao, High-tech enterprise evaluation, CITIC Publishing House, Beijing, 2002.

[5] H.S.Wang, Business Valuation, Fudan University Press, Shanghai, 2005.

[6] R.Ariane, Investment in Innovations and Competition: An Option Pricing Approach, The Quarterly Review of F-economics and Finance, 38(1991) 32-45.

[7] J.L.Shang, The mathematical model and option pricing methods, Higher Education Press, Beijing, 2003.

[8] G.Li, T.Jie, Real option in high-tech enterprises in the start-up investment decision application, Technology Progress and Policy, 5(2007)561-577.

[9] Z.J.Wang, K.C.Wen, Comment by real option evaluation of R \& D project status and trends, Technology Progress and Policy, 4(2007)32-55.

[10]Z.M.Cheng, Financial Computer Course-MATLAB Financial Toolbox Application, QingHua University Press, BeiJing, 2009. 